State-Wide Trends in School Hygiene and Physical Education

office of Education

Pamphlet $N_{0} \cdot 5$

$116.43: 5$ 
8086 '12 avr IVd

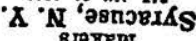

-oul 'sodg pIo[אहg]

sөpu!g

folydured

tunowopoyd 


\title{
LIERARY
}

- TEXAS techinOLOGIC" " .

LUEEOCK, TEW...

Pamphlet No. 8

May, 1930

UNITED STATES

DEPARTMENT OF THE INTERIOR

RAY LYMAN WILBUR, SECRETARY

OFFICE OF EDUCATION

WILLIAM JOHN COOPER, COMMISSIONER

WASHINGTON, D. C.

\section{STATE-WIDE TRENDS IN SCHOOL HYGIENE AND PHYSICAL EDUCATION}

\author{
As Indicated by Laws, Regulations, and Courses of Study \\ By JAMES Frederick Rogers, M. D. \\ Consultant in Hygiene and Specialist in Health Education, Office of Education
}

A State law regarding any special educational activity may be said o represent the conservative degree of recognition of that activity iy the people of that State. There are all degrees of conservatism; lowever, and the statute may offer only a permissive toleration lead$\mathrm{ng}$ to local developments or it may command the full acceptance ind putting into active practice of a thoroughgoing state-wide rrogram according to the ideas of those especially interested and nformed. Always it means considerable interest in the subject, for he time being at least, of an influential group of citizens, although his may be made up only in part of educators.

When it comes to regulations of State departments of education or the development of special courses of study the subject in hand as been absorbed as an essential feature of the school program . hough again to a lesser or larger degree according to the attitudes of hose in educational authority in that State.

\section{Physiology and Hygiene}

No wave of legislation having to do with school hygiene and anitation has so swept the country as that accompanying the temerance movement. Every State passed a law requiring instruction $n$ regard to the effects of alcohol and narcotics; while for the Ter-

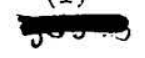


ritories a law to the same effect was established by act of Congress. While the requirement of instruction in the effects of alcoholic drinks and of narcotics (tobacco is mentioned in many of these statutes) was the first intent of these laws, it was recognized that such teaching belonged as part and parcel of the larger subjects of physiology and hygiene and these more general branches are required without limitation as to content by 40 States.

Practically all of the laws to this end were set up in or around the year 1880. While most of these laws did not decide the age at which these subjects were to be presented, some of them specified the grades to be taught and whether a text was or was not to be used in them. That the legislators were very much in earnest in some States is indicated by the requirement that the textbooks of physiology and hygiene should devote a specified proportion of their contents or a definite number of pages to the effects of alcohol. A number of the laws also stated very positively that physiology and hygiene should "be taught to and studied by pupils as thoroughly and in the same manner as other branches are taught and studied."

It is of interest that in 1929 the States of Delaware and New Mexico (in which the existing statutes were not very specific) passed laws requiring the teaching of the effects of alcohol and narcotics.

\section{Ventilation Laws}

The ventilation of schools has been and still is the most troublesome problem in school hygiene. In the nineties the carbon dioxide of the air, if not looked upon as a menace in itself, was at any rate set down by the ablest sanitarians as a definite gage of the degree of toxicity of the air caused by human "effluvia." When it was formulated by science that, in order to keep the carbon dioxide down to a certain concentration, and hence the poisonous animal matter in the air at a safe dilution, each child must have delivered to him 2,000 cubic feet of fresh air per hour, there was something definite on which to set up legislation. In consequence, ventilation laws or regulations on this subject were formulated by 31 States and in 20 of these States a standard was set of 30 cubic feet of air supply for each pupil per minute.

Although set up by the authority of science, scientists, or at any rate some scientists, after only a quarter of a century seem to regret that these specific requirements were ever put into effect and would demand their revocation. It is worth noting that for a number of weeks of the school year (when the furnaces are not in operation and when the health of the pupil is apparently at its best) the required amount of air is never delivered to the pupils. The doubt that has been thrown by recent studies on the value of the 
ventilation requirements of these laws (when the laws are fulfilled) should put a damper on legislation which is too specific in its demands.

\section{Medical Inspection}

Legislation and regulation with regard to the medical inspection of school children began in 1899 but was most active between 1910 and 1920, with minor changes in existent laws during that period and later. These laws present an astonishing variety as to details of requirements or permissions and are difficult to present in a simple classification. In all, 38 States have some kind of a statute or regulation (usually a statute) either permitting or requiring the examination of children for physical (and sometimes mental) defects. In addition, one State permits the establishment of dental clinics and in another State without a law there are local ordinances permitting medical inspection.

In 24 States the law is more or less mandatory in its wording for all school districts, and for certain districts in 3 other States. The State board of education is apparently responsible for carrying out the mandatory law in 11 States and is directly responsible in 8 of these. The State department of health is responsible for what is to be done in 11 and joint action is advised in 9 . However, the "responsibility" especially of departments of health seldom includes more than the prescribing of examination forms. In joint supervision this is usually the function expected of the department of health.

The local responsibility rests in 29 States with the board of education and in 7 with the board of health. In one it is placed jointly.

Only one State (New York) has by law a State director of medical inspection, although in three others some official of the State department of education or of health serves more or less exclusively in this capacity.

Examinations are "required" annually (presumably of all pupils) in 20 States; every two years in two and every three years in one.

Examination by teachers is specified by mandatory laws of 7 States, though usually for specified conditions, especially as regards defects of eyes, ears, nose, and mouth.

It is stated that the teacher may be one of the examiners in 11 other States. In 3 States a nurse is apparently the only examiner (in one of these she must be a "volunteer" nurse); and in 14 others she may participate in examinations.

A physician is specified as examiner in 5 States, the county health officer in 3 States, while in 20 the physician is mentioned as one of the examiners. 
In 3 States examinations of children seem to be limited to those of sight and hearing, in 1 to sight, hearing, and breathing; in 1 to sight, hearing, nose, and throat; in 1 to sight, hearing, breathing, and teeth; in 2 to dental defects, while a more general examination is specified in 15.

In one State only is examination made obligatory, the parent being fined $\$ 5$ or put in jail for 10 days "for each refusal" to permit examination. In another State a child who shows a serious defect must be brought by the parent before an agent of the State board.

Failure to comply is punishable by a maximum fine of $\$ 50$ or 10 days' imprisonment. However, "written objection from the parent exempts the child from examination."

- In one State not more than 10 cents each is to be paid for examinations from school funds.

A few States have a law or regulation requiring the examination of the teacher for tuberculosis or other disease, but these are not included in the above 38 States.

\section{Physical Education}

About 10 years after the passing of the laws requiring the teaching of physiology and hygiene to all pupils, there occurred a widespread introduction by large cities of a period of physical education, or in the more accepted wording of the day " calisthenics;" into their school programs. Lessons from 5 to $\mathbf{3 0}$ minutes in length were given, usually once, but sometimes twice a day. These activities were intended especially to counteract the effects of the sedentary life of the school, though much more was expected from their use. They were considered of especial importance for city children, as having fewer facilities for physical activity than their country cousins.

At the time there was no national organization aiding the cause of physical education. In certain localities, however, the Turnverein was influential and it was this society which was instrumental in securing the passage, in Ohio, in 1892, of a law requiring the inclusion of physical education "in the branches to be taught in public schools of cities of the first and second class."

Commenting on the passage of this law the editor of "Physical Education" in the September, 1892, issue remarks "The National Women's Christian Temperance Union is taking hold of this matter with great vigor and will endeavor to have similar laws passed in other States." However, no further legislation on this subject occurred until North Dakota passed a bill in 1899. This State made "physical education" a required subject in all common schools, and declared it the duty of "all boards or educational institutions receiving money from the State to make provision for daily instruction in all schools and institutions" under their jurisdiction. 
No further laws of this nature were passed until about 1910, bytyt since that date the number of States with:such legislation has ragehed 36. The statutes are practically all mandatory in effect, at least so far as requiring the furnishing of instruction in the subject is concerned. In one State the law refers only to high schools and in another it does not include high schools.

While not all States have laws on this subject the importance of płalysical activities is stressed in the courses of study of 42 .

- 1. In 25 States a certain time to be devoted to physical activities or to:instruction in such activities is specified by law or by regulation, while in most of the others a definite time is suggested in the State course of study. For elementary schools, one State specifies a minimum of 6 minutes, two States 8 minutes, one 12 minutes, six 15 ininutes, two 18 minutes, nine 20 minutes, seven 25 minutes, five 30 minutes. (The requirement is often a total for the week with the above equivalents in daily practice.) One law specifies at least 15 minutes in each school day and " at least one hour of directed play outside regular classroom work in each week" for elementary and two hours for high school pupils.

In one State three hours per week is suggested which "should be exclusive of any time devoted to physical activities before or after school but should include recess periods."

In another State 120 to 180 minutes per week is required under supervision or direction of school officials which may be covered in the recess periods or after the other work of the day is completed. In addition, there is a requirement of three hours per week, supervised or unsupervised, which may be taken care of by an agency other than the school (if satisfactory to the school authorities), making a total minimum of four hours per week.

In another State 250 minutes of plays and games are suggested for Grades I-II, 200 minutes for Grades III-V, and 150 minutes for Grades VI-VIII, but apparently these activities are to be carried on at recess and noon periods.

In at least 13 States the physical education period may be borrowed in part (and often altogether) from the recess period and u'sually the specific time does not exceed these recess periods. Some States require specifically that all recess periods be considered physical education periods. In nine States it is made plain that the recess period is not to be considered as a part of the time devoted to physical education though one of these States suggests that the school organize the activities of this period "in self-defense." Another of these States suggests organized activities directed by pupils at this time.

Three States announce emphatically that it is as much the business of the teacher to be on the playground at recess and at the noon 
hour "directing and encouraging play as it is to teach any subject in the curriculum "; and one course of study reads "Play at recess during good weather should be compulsory." One course of study recognizing the limits of the usual prescribed period for physical education states that "for developing bodily vigor, and improving action of vital organs, an hour a day or more is needed."

The course of study of one State in which the time requirement is exclusive of recess says, however, that "all recess periods are to be considered physical education periods." Another State department says "Recess should be limited in usage to those which are in truth recesses. It should not be used to designate physical education." This apparently contradictory advice is due to the fact that the "physical education period" in this instance is considered by the State authorities as instructional. Very few States as yet take this view of the matter verbally and doubtless there hangs over from an earlier period the impression of an all-sufficient influence, physical, mental, and moral, once believed to be exerted by calisthenic exercises rightly directed for a few minutes a day.

In the days when gymnastics or calisthenics were the sum and substance of physical education so far as any activities under that name in school were concerned (from the introduction of "physical training" up to about 1910) the period set apart in the school schedule for this purpose and the activities carried on were an end in themselves. While the efforts of the teacher were instructional it was not expected that the exercises taught would be repeated by the pupil of his own volition at any other time or in any other place. It was taken for granted that the pupil would carry on his more active physical education through the traditional games of the playground. It became more and more evident, however, that these traditions were (because of racial mixtures, small families, overrefinement in dress, from growing school buildings, shrinking school grounds, and other causes) not being carried on. As the Montana Course of Study puts it, "children inherit play but they do not inherit games," and the knowledge of games was more or less lost. Because of the importance of the old games in the life of the average child, it became apparent to the physical educator that these activities (which had always been of vastly more importance than any formal gymnastics) must be taken up as a matter of instruction and, where needed, given supervision. The time assignment for the lesson, under the new concept of physical education, is considered chiefly as one for instruction in games, while the recess period is the time for putting into practice what is taught with only such supervision as is needed for the unhampered enjoyment of the activities that have been learned. The varying physical education "requirements" of different States 
or of local schools are absurd, considered in any other light, for either the 10 minutes a day or one period a week in the program of one school must be too little, or the 60 minutes a day, or five periods a week required in another must be too much. Certainly the period set apart in the regular school schedule can only be considered a "drop in the bucket," so far as the needs of opportunity for play of the average child are concerned. Whether any requirement as to time to be spent in physical activities out of school hours should be made (as is the case in two States) may be questioned. While the healthy child, if unhampered, usually finds outlet for superfluous activity in the playing of the active games with which he is acquainted it does not follow that because a child is required to play these games he will become more healthy in body or mind or a better social creature. There are other outlets nowadays for nervous energy and compulsion along this line may not bring about expected results. While ample opportunity and encouragement.should be furnished this is probably as far as we can safely and logically go.

There is left over as a physical education activity of the school schedule, finding its end at the time and in itself, the remains of the former formal gymnastic lesson in the two-minute relaxation period or "relief drill." Thirteen States in their courses of study recommend these periods. Five States advise its observance twice a day, two States three times, two States three or four times, two States four times, one State "in each sitting period" and one "when needed."

Some years ago one of the European countries in a fit of economizing abolished its military bands. They were not long in finding their mistake and they now have larger and better bands. Not long ago many educators concerned lest the child's mind be not fully unfolded or informed sought to do away with the recess period. It was a serious mistake and was found to be so.

The recess periods (traditionally 15 minutes in the morning and 15 minutes in the afternoon) should not be encroached upon by the work of the school and any time allowed for physical activities in addition to the time cluring the school session given over to instruction in, or practice of, such activities is not likely to be in excess of the needs of the child along this line.

The fact that a generation ago the physical educator gave the recess period no formal recognition while he now insists upon its great importance in his program is not a piece of inconsistency, for though the importance of class exercises in gymnastics has declined, he always looked upon games and athletics as of prime moment. The difference is that, in the sociological changes which have come about, it becomes incumbent on him to assume the responsibility for 
the activities of the outside or inside playground (gymnasium) in the way of supervision if not of instruction.

In high schools, while about the same amount of time is suggested or required for physical education as in the lower grades, this time is usually condensed into two or three periods per week. As about half of the period is usually spent in dressing, calling the roll, and in bathing, there are not many minutes left even for instruction. As adequate weekly allowance for physical activity it is absurdly small.

In the high school the playing of active games now requires a suitable costume combined with a place to play, indoor or out. While the latter is furnished (and it ought to be furnished) by the community (probably best through the schools) there should be sufficient supervision for all pupils whose energy and inclinations lead them to participation in active games. This is now done for those preparing to uphold the name of the school in a "life or death" struggle to win, in which some one must always lose. It is only fair that the privileges of supervised play should be as freely extended to all who desire them.

The logical tendency then would seem at the present time to be toward a shortening of the scheduled period (of instruction) and an extension of the opportunity after school and on Saturdays for sufficiently supervised play. Evidently Oregon has come to this conclusion, for in its course of study it states "The play field and equipment should be available at all times for use. This includes the period after school and on Saturdays."

With the passing of the physical education class as an end in itself, and an attempt to furnish the pupil with opportunity to practice what is taught him there follows the need for larger and better-surfaced playgrounds and a change from the traditional type of gymnasium to an indoor play field.

The need for space and supervision of physical activities extends beyond the school. They are as much a recreational need of the community. Community and school become merged in this regard just as the home and school are mutually interested in the efforts to preserve or improve conditions affecting the health of the child.

\section{Health Education}

The way for the more active methods of teaching hygiene known as "health education" was prepared legally long ago in the laws previously mentioned which require the teaching of "hygiene and physiology." Also many of the physical education laws specify the teaching of information in regard to factors affecting health while the teaching of " health habits" is mentioned in many of them. 
Suggested 80 years ago by the Boston school examiners, the "health habit" idea has been generally adopted and 45 States in their courses of study outline in more or less detail methods of health-habit teaching. In two States the course of study recommends, or the physical education law requires, that in the first 6 to 8 grades, 5 minutes of each day be devoted to health education; in one, 8 minutes; in five, 10 minutes; in three, 12 minutes; in three, 15 minutes. Lessons are to be given once a week in 5 States, twice per week in 3 , and three or four times in 1.

One of the States would carry regular instruction to and including the ninth grade, one the tenth, and one the eleventh.

A textbook is mentioned in 30 States. Its use is begun in Grade III in 2 States, in Grade IV in 8, in Grade V in 7 , in Grade VI in 6, in Grade VII in 4, and in Grade VIII in 2. A text for elementary grades is not mentioned in the remainder. A number of States suggest the desirability of correlation of hygiene with other subjects of the curriculum. One says that " hygiene must be taught everywhere throughout the school course," the time and effort spent to "depend upon the home environment and community."

In grades beyond the seventh or eighth there is little systematic teaching of physiology and hygiene. It is covered in a brief, betterthan-nothing way in the course in general science or in the course in biology, but these are usually studied by comparatively few highschool students. In one State one or two 45-minute periods per week of hygiene is recommended for high schools. In another; health education may be administered either as five 40 -minute periods per week for one semester or one period for five semesters. In another State "community hygiene" is to be taught in the ninth, tenth, and eleventh grades "chiefly by discussion and talks, the pupils taking notes." In another, one period per week is required throughout the high-school course. In another, one hour of general science is required in the eighth and one-half hour of physiology in the ninth grade with 18 to 25 laboratory experiments included. Biology is recommended as forming " in part " a proper basis" for human physiology in the ninth or tenth grade and physiology is recommended as elective for the eleventh and twelfth grades.

Shouldered as this "most important of all subjects" is by many things required for college entrance we are a long way from what would seem to be adequate instruction along this line in the higher grades such as might be brought about by a course in general science in the ninth grade, a demonstration course in elementary biology in the tenth, a thoroughgoing course in physiology and hygiene in the eleventh, and practical teaching of home and community health in the twelfth. 
As a check upon the carrying out of laws or regulations graduation requirements in physical education (which may include health instruction) are made in some States as follows: Alabama, 1 year; California, 4 years; Connecticut, Florida, Iowa, 4 years; Maine, 4 years; Minnesota, 2 years; Missouri, 2 years; New York, 4 years; North Dakota, 2 years; Ohio, 4 years; Pennsylvania, 4 years; Rhode Island, 4 years; Virginia, 4 years; West Virginia, 1 year; and Wisconsin, 4 years.

While the teaching of hygiene is included under physical education in some of these States, a specific requirement in " physiology and hygiene" is made only by New Mexico (one year) and in "health work" (for girls, 2 years) by Alabama.

Time was (and not long ago) when physical education included instruction in hygiene and sanitation ("health education") and that their divorce was largely one of words is indicated by the inclusion of hygiene in most "physical education" laws and by the fact that most State directors of "physical education" are also "directors of hygiene." The following States now have either directors of "health," of "physical education," or of "health and physical education": Alabama, California, Connecticut, Delaware, Florida, Illinois, Maryland, Massachusetts, Michigan, Minnesota, Missouri, New Hampshire, New Jersey, New York, Ohio, Pennsylvania, Virginia, and West Virginia.

\section{Summary}

Looking back over the half century in which health work in schools has received state-wide recognition it is evident that there has been unquestioned acceptance of physiology and hygiene as a part of the curriculum at least in elementary schools, and quite specific directions have been given as to what should be done in these schools. There is rather general neglect of these subjects, however, in the period of senior high-school life.

As regards physical education there is a similar widespread recognition, but both the laws and the courses of study reflect the transition from the old gymnastic period, considered sufficient in itself, to an instructional period chiefly devoted to games or rhythmic activities, with provision by the school (or other civic agency) of opportunity at recess, after school and on Saturday for the unhampered practice of these activities.

The great variety of legislation for medical inspection is indicative of an activity which is more or less new, which is but little understood either by schoolmen or the laity, seems in a way outside the realm of education, and is tinged with popular prejudice against interference with the ways of nature as exhibited in bodily faults and disease. Modifications in these laws are, however, being made 
from time to time, while the importance of the removal of defects and prevention of disease and the relation of health to school progress are becoming better appreciated.

TABLE 1.-Summary of State Legislation on Physical and Health Education

[Key-M, indicates mandatory law; $P$, permissive law; $Y$, yes]

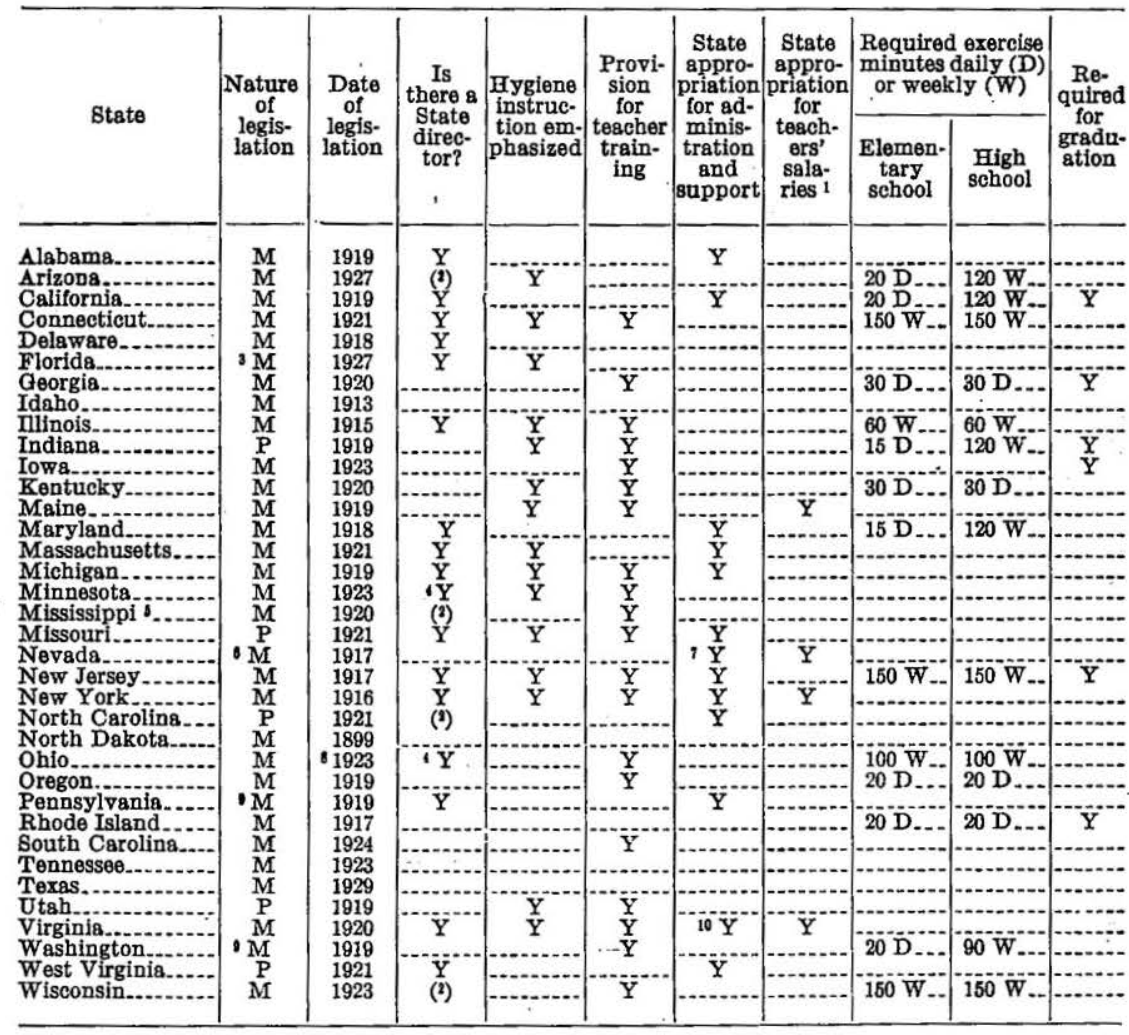

1 It is doubtless true that in many of the States providing State aid for local teachers' salaries this aid applies to the salaries of special teachers of physical education.

2 Provision for director but office not filled.

Regulations made by State board of education.

1 Not mentioned in law.

$\checkmark$ The provisions of the Mississippi Act shall become effective only upon condition that the Federal Government provides funds dollar for dollar with the State of Mississippi for carrying out the provision of this act.

For high schools, permissive elsewhere.

7 Based on state-wide taxation.

Revised.

- Not for high schools.

10 Supervision covers medical inspection also. 
TABLE 2.-Summary of State legislation for medical inspection

\begin{tabular}{|c|c|c|c|c|c|c|c|}
\hline State & Law & $\begin{array}{l}\text { State author- } \\
\text { ity } 1\end{array}$ & Local authority & $\begin{array}{l}\text { Manda- } \\
\text { tory or } \\
\text { permis- } \\
\text { sive }\end{array}$ & Examiner & How often & Extent of examination, etc. \\
\hline Alabama... & $\begin{array}{l}\text { Yes.. } \\
\text { Yes.. }\end{array}$ & Joint... & $\begin{array}{l}\text { Joint } \\
\text { Education..... }\end{array}$ & ${ }^{2} \mathrm{M}$ & $\begin{array}{l}\text { County health officer } \\
\text { Physician and nurse }\end{array}$ & Annual. & Any defect and deformity. Physical and montal. \\
\hline $\begin{array}{l}\text { Arkansas } \\
\text { Callfornic }\end{array}$ & & & Education. & $\mathrm{P}$ & "Physicar inspector" certified by & & ' \\
\hline $\begin{array}{l}\text { Colorado } \\
\text { Connecticut.-. }\end{array}$ & $\begin{array}{l}\text { Yes.. } \\
\text { Yes.. }\end{array}$ & Education & (ndo & $\stackrel{M}{M}$ & $\begin{array}{l}\text { State. } \\
\text { Teacher- } \\
\text { Physician, nurse, teacher, optom- }\end{array}$ & Annual.. & $\begin{array}{l}\text { Sight, hearing, breathing. } \\
\text { Vision for all. Other defects where physician is }\end{array}$ \\
\hline $\begin{array}{l}\text { Delaware..........-. } \\
\text { Florida }\end{array}$ & $\begin{array}{l}\text { Yes.-. } \\
\text { Yes... }\end{array}$ & Health-... & Heslth & $\stackrel{P}{\mathrm{P}}$ & Physician and nurse & & employed. \\
\hline Georgia. & Yes & .......do_ & ......do. & ${ }^{2} \mathrm{M}$ & $\begin{array}{l}\text { County medical inspector......... } \\
\text { Commissioner of health............ }\end{array}$ & Annual. & $\begin{array}{l}\text { (No physician shall be assigned more than } 2,500 \\
\text { children.) } \\
\text { General examination. }\end{array}$ \\
\hline Illinois........................... & No... & & & $\cdots$ & & & \\
\hline Indiana & $\begin{array}{l}\text { Yes..... } \\
\text { Yes }\end{array}$ & Joint .... & Education.-. & $\mathbf{P}$ & Physician & & $\begin{array}{l}\text { General. } \\
\text { Dental. }\end{array}$ \\
\hline $\begin{array}{l}\text { Kansas } \\
\text { Kentucky................... }\end{array}$ & $\begin{array}{l}\text { Yes..... } \\
\text { Yes....- }\end{array}$ & Heaith........... & Health & M & $\begin{array}{l}\text { Dentist- } \\
\text { County health officer and public }\end{array}$ & Annual..... & Do. \\
\hline $\begin{array}{l}\text { Louisiana } \\
\text { Maine........................ }\end{array}$ & $\begin{array}{l}\text { Yes... } \\
\text { Yes... }\end{array}$ & $\begin{array}{l}\text { Joint........ } \\
\text { Education. }\end{array}$ & Education..- & $\stackrel{M}{M}$ & $\begin{array}{l}\text { nealth nurse. } \\
\text { Teacher } \\
\text { Teacher or physician }\end{array}$ & Annual. & $\begin{array}{l}\text { Sight, hearing, and diseases of eyes and ears. } \\
\text { Sight, hearing, and any other defects interfering }\end{array}$ \\
\hline Maryland....--.. & Yes... & Joint...... & .......do & $\mathbf{P}$ & Physician & At least every & $\begin{array}{l}\text { with school progress. } \\
\text { Do. }\end{array}$ \\
\hline Massachusetts... & Yes.. & .....do_. & ......do_. & M & $\begin{array}{l}\text { Physician; teacher for sight and } \\
\text { hearing. }\end{array}$ & Annual... & $\begin{array}{l}\text { Sight, hearing, and any other defects interfering } \\
\text { with school progress. (Teachers to be instructed } \\
\text { in normal schools.) }\end{array}$ \\
\hline $\begin{array}{l}\text { Minnesota } \\
\text { Mississippi } \\
\text { Missouri }\end{array}$ & $\begin{array}{l}\text { Yes..... } \\
\text { Yes..... } \\
\text { Yes..... }\end{array}$ & $\begin{array}{l}\text { Joint. } \\
\text { Education. } \\
\text { Health }\end{array}$ & Education... & $\stackrel{M}{M}$ & $\begin{array}{l}\text { Physician, nurse, and teacher.... } \\
\text { A vailable agencies. } \\
\text { Physician, nurse, supervisor of }\end{array}$ & Periodic & · \\
\hline 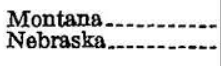 & $\begin{array}{l}\text { Yes..... } \\
\text { Yes..... }\end{array}$ & Healtb...... & (ndo & $\begin{array}{l}\mathbf{M} \\
\mathbf{M}\end{array}$ & $\begin{array}{l}\text { physical education. } \\
\text { Physician } \\
\text { Teacher }\end{array}$ & Annual... & $\begin{array}{l}\text { General health conditions. } \\
\text { Sight, hearing, teeth, mouth breathing, and com- }\end{array}$ \\
\hline $\begin{array}{l}\text { Nevada } \\
\text { New Hampshire.... }\end{array}$ & $\begin{array}{l}\text { Yes.-...- } \\
\text { Yes.-... }\end{array}$ & Éducation & - do & $\begin{array}{l}\mathrm{M} \\
\mathbf{M}\end{array}$ & Physician; teacher for eyes and & -....do do & municable disease. \\
\hline New Jersey...... & Yes...... & & & M & $\begin{array}{l}\text { ears. } \\
\text { Physician or nurse }\end{array}$ & & Any defects, also growth and development (annu- \\
\hline $\begin{array}{l}\text { New Mexico } \\
\text { New York...-...-. }\end{array}$ & $\begin{array}{l}\text { No... } \\
\text { Yes.. }\end{array}$ & Education.... & Education.: & $\ddot{M}^{-\cdots}$ & $\begin{array}{l}\text { Physician; teacher for eyes and } \\
\text { ears. }\end{array}$ & Annual... & $\begin{array}{l}\text { Vision and hearing by teachers. (Teachers to be } \\
\text { trained.) }\end{array}$ \\
\hline
\end{tabular}




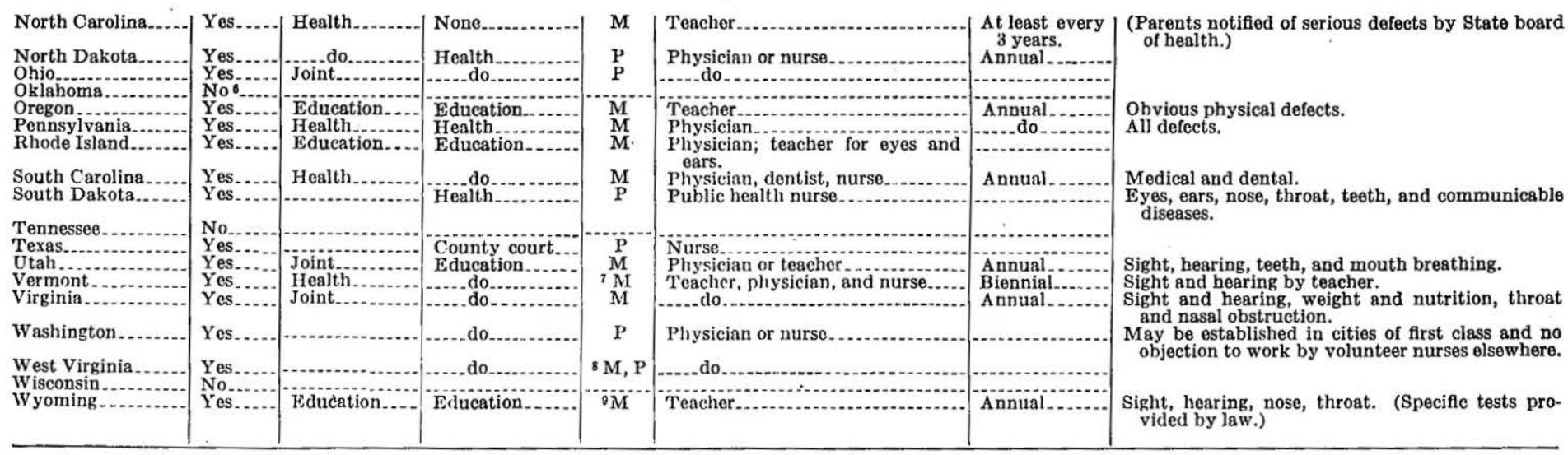

1 State "authority," espocially as regards the department of health, is seidom more than that of preparing blanks for examinations.

? Where there is a county health officer.

Power to establish dental clinics.

"Free dental examination required. First and second class cities and "in school districts."

- Has some local ordinances.

Sight and hearing.

Man intory for independent, permissive for other districts.

P For incorporated cities and towns. More or less mandatory, 27, permissive, 13.

U. S. GOVERNMENT PRINTING OFFICE: 1930

For sale by the Superintendent of Documents, Washington, D. C

LIBFARY

Price 5 cents

TEXAS TECHNOLOGICAL CO:

LUBBOCK, TEXAS 




